\title{
(c) $\underset{10}{(1) \Theta}$
}

\section{The conflict of sacred and contaminant: The impurifying effects of tourism in Sámi sacred sites}

Eleonora Alariesto, University of Lapland, Tourism Research, Arctic Studies and Sámi and Indigenous Studies

\section{Tourism in Sápmi and sacred sites of the Sámi people}

Tourism is one of the fastest growing industries in the Sámi homeland, Sápmi. The rapid growth of tourism also leads to increased environmental impacts, such as littering and erosion (Hemmi, 2005, pp. 31-34). As tourism keeps on growing in the north, the popularity of Sámi sacred sites also continues to increase when, for example, social media posts spread featuring these unique places of natural wonder. As tourism takes over these sacred sites, their very sacredness itself is endangered, which is a matter of concern. Sacred sites are not only culturally and historically important locations, but they hold great value for the cultural heritage, generational spiritual connections and identities of Sámi communities (Kuokkanen \& Bulmer, 2006, p. 217). This fact is why the matter of the protection of these sacred sites is very topical and must be taken into account. As a Sámi person myself, I also carry the collective concern for these sites along with the Sámi community.

In October 2019, archaeologist Eeva Harlin and ecologist Inka Musta composed an opinion piece in the most widespread print media of Finland, Helsingin Sanomat, about the sacred sites of the Sámi people. Harlin and Musta stated that Australia has preserved the sacred rock of Aboriginal people, Uluru, and that the same preservation process should be applied to Ukko's rock (Äijih, in Inari Sámi) at Lake Inari (Figure 1). In the opinion piece, the two writers described the meaning of the rock to the local Sámi people and suggested it be preserved and landing on it forbidden. After the publication of the piece, a local tourism business in Inari announced their intention to quit landing on the rock out of respect for the indigenous community. Not long after this decision to stop lake cruises to the rock, Metsähallitus (Finnish Forest and Park Services) decided to take down the infrastructure built on the island, such as the wooden stairs and concrete dock. 


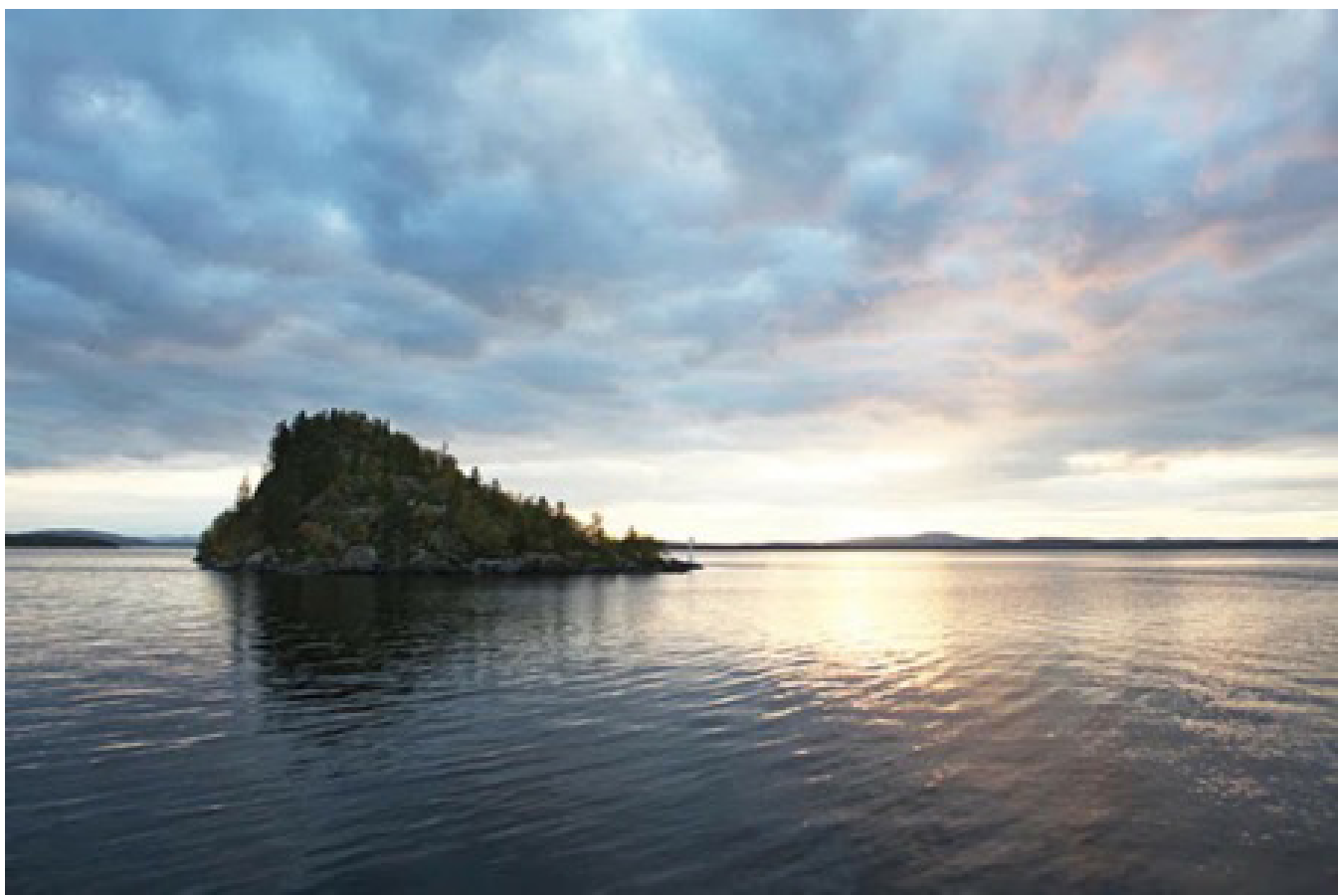

Figure 1. Ukko's rock (Ukonkivi, Ukko, Ukonsaari, Äijih). Photo: Tapio Heikkilä, Ministry of the Environment.

In their article, Harlin and Musta explored the behaviour of the visitors and how they littered on the rock. The piece forms the centre of my research: I examine the different forms of contaminants appearing at the Ukko's rock sacred site using the theory of impurities (Douglas, 2000; Lagerspetz, 2008). Understanding different forms of contamination at indigenous sacred sites deepens our comprehension of the impacts caused by tourism. This kind of knowledge is essential when tourism is accelerating at sensitive locations, because the impurifying intensifies and thus the need for protection and prevention of contamination grows.

In the core of ethical Sámi and indigenous studies is the matter of the researcher's independence: the need to create new information without adding pressure to indigenous communities, which has been the source of Western research-centered science (West, 2018). Because of this matter, my material is based on news articles in different media outlets and the opinion piece written by Harlin and Musta. Using materials that already exist is one way to avoid increasing pressure on indigenous communities.

When Sámi cultures are the major element of a tourism business, cultural sensitivity should be included in its methods of performing its tourism activities (Kugapi et al., 2019, p. 8). Thus the opinion piece is the centre of my research analysing the dimensions of contaminant. The piece represents the voices of the local Sámi community, as Inari Sámi Musta and archaeologist Harlin speak out on behalf of the cultural importance of the rock. 


\section{What is contaminant?}

The human experience of contaminant is subjective, and what may seem to be litter, dirt or impurity to one might not manifest as such to another person (Lagerpsetz, 2008, pp. 33-34). The experience is highly affected by people's mindset, or a so-called "handbook", an idea presented by cultural anthropologist Mary Douglas (2000, pp. 85-86). The handbook is shaped in different sociocultural environments and influences everything to do with our behaviour and ways of thinking. This mindset is unique to every culture and defines the state of norms in different subjects. Douglas presents the example of shoes, which are not dirty in themselves, but are dirty when placed on the dinner table. Our mindset disapproves of these objects in this setting, and we thus call out the act as something dirty. This kind of categorising is based on the idea that norms dictate what belongs where. Dirt, impurity or contaminant occupy a leftover category for subjects, objects that do not fit into the norm (Douglas, 2000, pp. 85-86). In this paper, I choose to use the concept of contaminant, since it is the most neutral word used to describe something that is not concrete litter or dirt from nature.

Contaminant requires two different initial aspects of existence: relations that fit within particular systems and those that break from these systems. In other words: where there lies contaminant, there is a system (Douglas, 2000, p. 86). In the process of forming contaminant, the essential components are matter and a host object, which each have different roles: primary and secondary. The primary host is defined by its telos, the all-encompassing meaning of the object in matter, which the contaminant is threating. The dirtiness of the secondary object occurs in relation to the primary object's telos. Primary objects' purity is considered important, and they are cleansed and protected from contaminants. Secondary objects are avoided and cleansed so they will not impurify the primary object (Lagerspetz, 2008, p. 45).

To understand impurity, one must comprehend the host object and its function. Dirtiness can be considered a process similar to breaking. The object in particular is understood by knowing how the object differs from its normal state when breaking or being impurified. This comprehension can be drawn from exploring the chosen cleansing methods, since extracting dirt requires knowledge and understanding of the character of the impurifying contaminant. This knowledge is not based on the know-how of cleaning but rather on comprehension of what is contaminated in the object and what cleansing methods are not to be used. Thus, impurities are an essential part of the host objects' identities, since they shape the function of the objects (Lagerspetz, 2008, p. 42).

At the core of contaminant lie substance and accident, which are the primary and secondary features of the object. The substance is the object in question in its normal, clean and undamaged state. Accident refers to all the dirt, stains and detritions that attach themselves to the host object without changing its identity. The fact it is possible to break the contaminant from the host object means that the process of impurifying must be temporary. If the contaminant is not able to be removed, it becomes a permanent attribute of the host object (Lagerspetz, 2008, p. 40). 


\section{The different dimensions of contaminant at Ukko's rock}

To analyse the different dimensions of contaminant at Ukko's rock, one has to know the normal "well-being" state of the primary host object, which is the sacred sacrificial sieidi rock. The telos of something lifeless cannot be examined by the means of natural science, so the host object and its telos are determined by people (Lagerspetz, 2008, p. 45). In the context of Ukko's rock, knowledge of the rock's telos is handed down through the generational knowledge of the local Sámi people, who are represented by the opinion piece written by Harlin and Musta. The subjective experience of the contaminant is also understood from the aforementioned "handbook", which defines the norms of objects (Douglas, 2000, pp. 85-86). In my research, I intuitively break down the impurity into three forms: physical, social and cultural dimensions and forms of contaminants (see Figure 2, p. XX).

\section{Physical contaminant}

In the opinion piece, the tourists are said to litter, damage flora and stray from the official routes. In the research material it also becomes clear that tourists have urinated and defecated on the rock. All of these acts done to the rock are called disrespectful by Harlin and Musta, which means they differ from the "handbook" of the local Sámi people.

Urine and faeces are not dirty in themselves, but once they touch a sacred site, they transform into contaminant, since they do not belong to the norm of the system of that site according to the "handbook" of the local Sámi people. Straying from official routes also increases the contamination of the site, because unnatural objects penetrate the nature of the rock (Lagerspetz, 2008, pp. 255-256). Impurifying unnatural objects include the litter left behind by tourists, which spreads out to a wider area when visitors leave the official marked routes on the rock.

\section{Social contaminant}

When analysing the social contaminant on the rock, our attention is drawn to the human visiting the site. This kind of contaminant focuses on living creatures, so here one must also consider humans as dirty and impurifying. In the context of Ukonkivi, the human is a secondary host object, endangering the purity of the primary object: Ukko's rock. Human thoughts, behaviour and professions can also be dirty or clean (Lagerspetz, 2008, s. 260).

In the opinion piece, the behaviour of the tourists is described as ignorant and disrespectful. A human's thoughts and behaviour can be dirty, and the demeanour of the tourists diverges from the normal system of the rock. This kind of impurifying social contaminant takes the form of consuming snacks and alcohol and straying from official routes. All of these acts are mentioned in the opinion piece as those that disrespect the sacred site.

When humans are contaminated themselves or could contaminate something else, the person is dirty in the same way as other objects. A person becomes dirty like objects when something disruptive attaches to that person (Lagerspetz, 2008, p. 277). When a person is contaminating or dirty, the person becomes the substance in the wrong place and system - in the case of Ukko's rock, they are at the sacred rock. In the material, it is evident that today's local Inari Sámi people do not have a tradition of landing on the sacred rock. Thus, it can be determined that such landing is something that is not a part of the pure and normal system of the rock, and 
this is why the writers propose that the rock should be preserved and landing forbidden. In the opinion piece, the writers do make clear that they have no desire to forbid all tourism of sacred sites; however, they wish for better information and guidance, so tourists would know how to act respectfully at sacred sieidi sites.

\section{Cultural contaminant}

The usage of sacred sites in tourism has been - and continues to be - problematic, and tourism can be seen to involve ethnographic exploitation (Ruotsala, 1998, p. 95, as cited in Äikäs, 2011, p. 147). Tourism can be seen to secularise the sacredness of sites, but it can also grow to become a part of the sieidi, creating new meaning for the site (Äikäs, 2011, p. 146).

At Ukko's rock there have been some signs of coins offered to the sacred rock. Usually these kinds of modern findings are left by tourists. Modern sacrificial gifts are connected to neo-shamanism, which is a sub-category of neo-paganism. Neo-paganism highlights the sacredness of nature and the connection between it and humans while connecting old European natural religions with the customs of today's natural ways of living. (Äikäs, 2011, pp. 123-129).

Neo-paganism and tourism represent the new meanings that sacred sites have gained outside the Sámi community. These new ways of using sacred sites can cause strong reactions, since different stakeholders may have differing perceptions of the meaning of the sites and the appropriate ways of using them (Äikäs, 2011, p. 146). The neo-paganism that takes place at indigenous sacred sites can be seen as a form of neo-colonialism involving cultural appropriation (Wallis, 2003, as cited in Äikäs, 2011, p. 146).

In the opinion piece, it is stated that sacred sites have been stolen and taken from Sámi people. Exploitative tourism and neo-paganism continue the colonialist past of the state's Christianisation by taking sacred sites from their traditional occupants, who have generational and social relationships with the site. By demonising spiritual rituals under the threat of death penalty, sieidis were also destroyed (Ranta, 2018, p. 86). In the piece, disrespectful tourism is seen as a threat to the sacred meaning of the rock. Hence tourism is also contaminant that threatens the normal and pure well-being of the rock, and ignorant tourism activities can been seen as cultural contaminant in the form of neo-colonialism.

\section{The future of sacred sites}

The conflict of sacred and contaminant is, at its roots, a land-use conflict. Putting aside the physical and more abstract forms of contaminant, the conflict is about a piece of actual land and the thorough questioning of who has access to it. The subject is very topical, because in the land-use conflicts in Sápmi, the forces and different sides of the conflict are usually the same: Metsähallitus, Sámi communities and some global, capitalistic force. Even now there are several projects for mining around Sápmi, and in the sacred land of Rástigáisa a windmill park is being planned. 


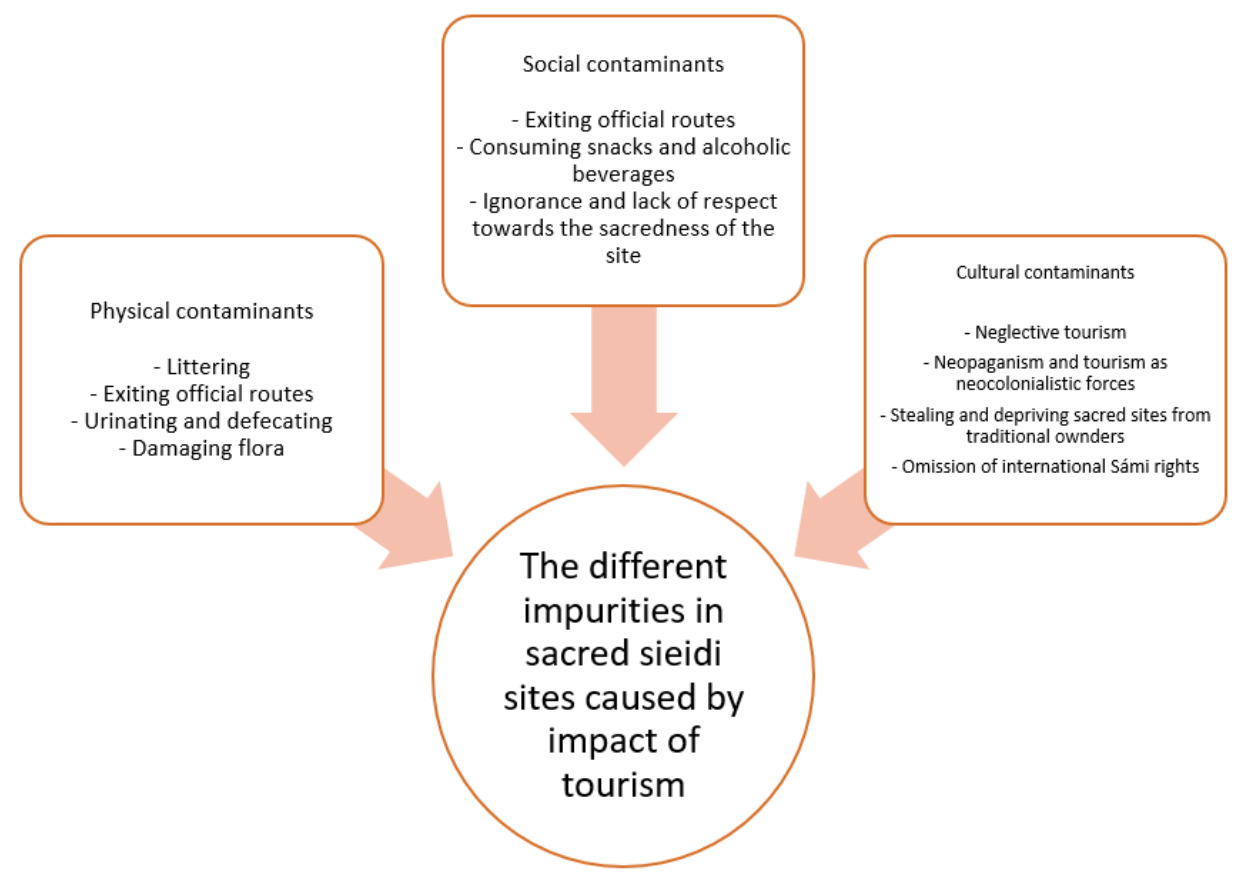

Figure 2. The different forms of contaminants in Sámi sacred places.

Prevention of land-use conflicts is essential, because every conflict is excessively overwhelming to Sámi communities. There are many examples in the past wherein indigenous communities have pled on the behalf of traditional lands, but those communities have not been heard. In 1960s, the state of Finland built the artificial lake Lokka in the Sompio area, forcing 650 Sámi and Finnish people to abandon their homes. In this time of structural colonialism and climate change, open communication, respecting indigenous land and declaring land rights are key elements in preserving indigenous livelihoods and cultures.

In Finland, the ratification of the United Nations' ILO 169 agreement would guarantee the Sámi self-determination and management of their traditional land and water, thus protecting their usage of cultural elements, for example from the tourism industry. Ratification of the agreement would help the progress of sacred sites, since the Sámi people would have decision power over sacred sites and their possible usage in tourism. In the year 2021, the Human Rights Committee of the United Nations recommended that Finland consider ratification of the agreement, which has been a topic of public discussion for decades. The Saami Council wants the agreement to be fulfilled, because then Finland would finally recognise the international rights the Sámi people have as an indigenous people (The Saami Council, 2021).

Furthermore, when protecting sacred sites, it is important to ensure the right of locals to use the sacred site, as these sites are still the subject of a wide range of activities. Sacred places provide a cultural connection with Sámi ancestors, and even if there are no longer active sacri- 
ficial rituals there, they are respected and considered essential to building Sámi identity (Äikäs, 2011, p. 146.)

\section{Acknowledgements}

The publication of this paper was supported by the Northern Periphery and Arctic Programme [Project No. 274; see: https://sensitivetourism.interreg-npa.eu/]

\section{References}

Douglas, M., Blom, V., \& Hazard, K. (2000). Puhtaus ja vaara: Ritualistisen rajanvedon analyysi. Vastapaino.

Hemmi, J. (2005). Matkailu, ympäristö, luonto: Osa 1. Suomen pienkustantajat.

Kugapi, O., Höckert, E., Lüthje, M., Mazzullo, N., \& Saari, R. (2020). Kohti kulttuurisensitiivistä matkailua: Suomen Lappi. (2. korjattu painos.) Lapin yliopisto.

Kuokkanen, R. J. \& Bulmer, M. K. (2006). Suttesája - From a sacred Sami site and natural spring to a water bottling plant? The effects of globalization in Northern Europe. In S. Washington, P. C. Rosier, \& H. Goodall (toim.), Echoes from the poisoned well: Global memories of environmental injustice (pp. 209-240). Lexington Books.

Lagerspetz, O. (2008). Lika: Kirja maailmasta, kodistamme. Multikustannus.

Ranta, K. \& Kanninen, J. (2019). Vastatuuleen: Saamen kansan pakkosuomalaistamisesta. Kustantamo S\&S.

The Saami Council. (2021, October 5). Saamelaisneuvosto: Suomen on korjattava ihmisoikeusloukkaukset ja ratifioitava ILO 169 -sopimus. Saamicouncil.net. https://www.saamicouncil. net/news-archive/saamelaisneuvosto-suomen-on-korjattava-ihmisoikeusloukkaukset-ja-ratifioitava-ilo-169-sopimus

West, H. (2018). Mitäs me väsyneet saamelaiset, maailman tutkituin kansa. https://helgawest. com/2018/11/09/mitas-me-vasyneet-saamelaiset-maailman-tutkituin-kansa/

Äikäs, T. (2011). Rantakiviltä tuntureille: Pyhät paikat saamelaisten rituaalisessa maisemassa. PohjoisSuomen historiallinen yhdistys. 